\title{
Stress Corrosion Cracking of Copper Alloys in Pure Steam and Water at High Temperatures
}

\author{
Shiro Sato and Koji Nagata \\ Research Department, Sumitomo Light Metal Ind., Ltd.*
}

\begin{abstract}
Several instances have been experienced in which copper alloy tubes used for feed water heater failed by stress corrosion cracking (SCC). An experimental study has been made to investigate the phenomenon of these failures using an autoclave in which the stressed and non stressed specimens were exposed to pure water and steam at high temperatures. The results obtained were as follows. 1) $\mathrm{Cu}-\mathrm{Zn}-\mathrm{Al}$ alloys showed different corrosion morphology according to the alloy composition in degassed steam at 150 to $300^{\circ} \mathrm{C}$. Namely, the low zinc alloys were liable to suffer intergranular corrosion, which developed to crack under applied tensile stress of 3 to $10 \mathrm{~kg} / \mathrm{mm}^{2}$. This phenomenon is considered to be the intergranular SCC in a broad sense. On the other hand the high zinc alloys had a tendency to suffer layer type corrosion and to be immune to the intergranular SCC. They, however, were deteriorated by creep rupture owing to intergranular cavitation under applied tensile stress of 3 to $10 \mathrm{~kg} / \mathrm{mm}^{2}$. 2) Cupronickel alloys, $90 / 10$ and $70 / 30$, suffered intergranular corrosion in pure water and steam at 300 to $350^{\circ} \mathrm{C}$. In the autoclave tests, intergranular SCC could be easily reproduced under applied tensile stresses of 15 to $20 \mathrm{~kg} / \mathrm{mm}^{2}$, independent of alloy composition, temper of specimen, steam temperature, and oxygen concentration in water. On the other hand, Monel metal was not failed under the experimental conditions of the pure water and tensile stresses up to $38 \mathrm{~kg} / \mathrm{mm}^{2}$. 3) It may be conclude that the SCC of copper alloys in high temperature pure water and steam is similar to the stress accelerated intergranular corrosion in a strict sense, which may be associated with the equilibrium grain boundary segregation of active metals.
\end{abstract}

\section{Introduction}

Copper alloys are widely used for heat exchanger tubes in many plants where high temperature water and steam are used, such as the feed water heaters of power plants, the brine heaters of salt refineries and of flash evaporators. Various instances of unexpected corrosion failures in these tubes have been experienced.

Klement et al. reported that the aluminium bronze (91-7-2/Cu-Al-Fe) used for condenser tubes and bolts in process industries failed quickly by the intergranular stress corrosion cracking in the steam at 180 to $500^{\circ} \mathrm{F}^{\prime \prime}$ Recently, O.S.W. reported the failures due to the cracking of aluminium brass tubes installed in the condenser of desalination plant with actual service time of $3048 \mathrm{hr}^{2)}$ These crackings originated from the steam side and penetrated through the tube wall intergranularly. It was concluded that they resulted from the season cracking caused by the presence of amine added for $\mathrm{pH}$ control and oxygen scavenging. Although it has been accepted as coppernickel alloys are free from SCC, the service experiences of tubes of these alloys in high-pressure feed

* 500, Ro-no-wari, Chitose, Minato-ku, Nagoya 455, Japan water heaters have revealed that the alloys were not always immune to SCC. Reynolds et al. reviewed on the problems of SCC in feed water heater. ${ }^{3)}$ Their experiences in fossile-fueled central stations indicated that $60 / 40-\mathrm{Cu} / \mathrm{Ni}, 70 / 30$ $\mathrm{Cu} / \mathrm{Ni}-5 \mathrm{Fe}$ and some of high strength Monel heater tubes had failed by SCC.

One of the authors has investigated the corrosion of binary copper alloys in high temperature steam and water. ${ }^{4}$ The results indicated that copper alloys suffered the corrosion which might relate to selective oxidizing reaction and that their corrosion morphology might be distinguished into two types, one is the layer type which is characteristic of $\mathrm{Cu}-\mathrm{Zn}$ alloy, the other is the intergranular type which is characteristic of $\mathrm{Cu}-\mathrm{Si}, \mathrm{Cu}-\mathrm{Al}, \mathrm{Cu}-\mathrm{Ni}$ and $\mathrm{Cu}-\mathrm{Mn}$ alloys. Therefore, it is suggested that the latter alloys susceptive of intergranular corrosion would easily be susceptible to SCC under tensile stress. However, there are little experimental investigations on the SCC of copper alloys in high temperature steam and water. In this paper we describe the typical instances of intergranular SCC in service and then discuss the results of accelerated stress corrosion tests in the autoclave under various conditions. 


\section{Experiences of SCC Failures}

We have often encountered with the SCC problems of aluminium brass tubes installed in salt refinery. ${ }^{5 !}$ They were exposed to high temperature steam at 150 to $220^{\circ} \mathrm{C}$ and cracked in a few months. Cracks originated from the outside (steam side) at the end of roller expansion and developed into the circumferential and the longitudinal direction. They suffered intergranular cracking accompanied by severe intergranular corrosion layer of 0.5 to $1.0 \mathrm{~mm}$. We had also the similar experi-
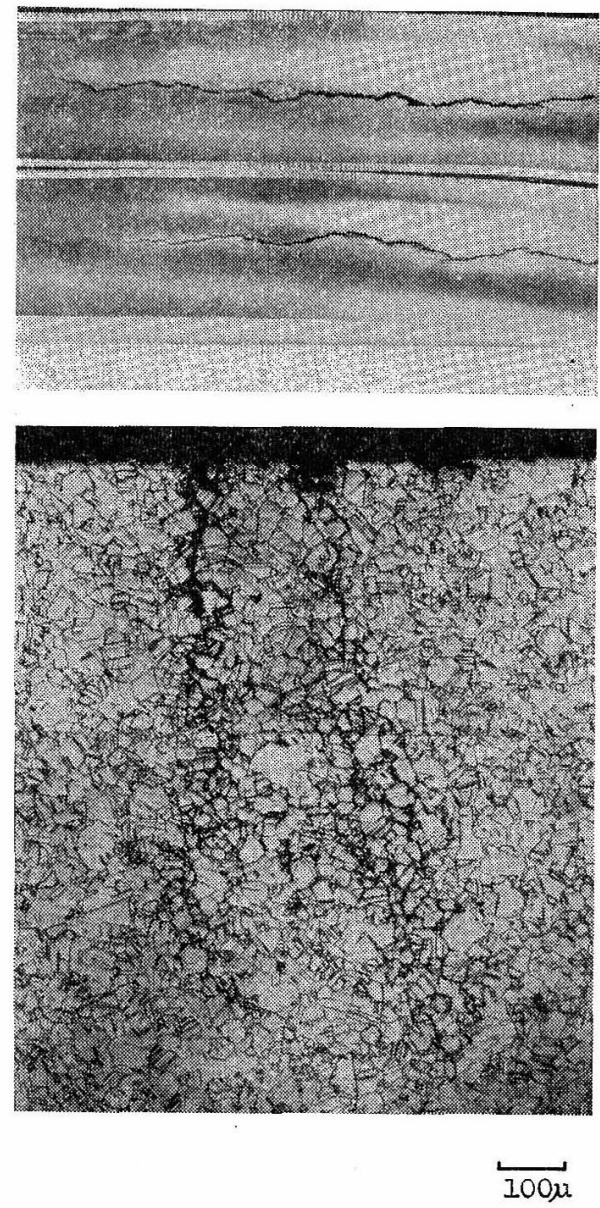

Fig. 1. Stress corrosion cracking of commercial aluminium brass used for heating coils. ences of aluminium brass tubes installed in the high-pressure feed water heater of power plants constructed during 1950 to 1960 in Japan. Moreover, aluminium brass tubes of heating coils used in oil refinery suffered stress corrosion failures. The failure originated from the inner side (steam of 150 to $160^{\circ} \mathrm{C}$ ) longitudinally at the portion of $\mathrm{U}$ bend. Figure 1 shows the typical appearance of the cracked tube and the microstructure of a fracture. It shows intergranular penetration accompanied by slight localized intergranular corrosion. These observations reveal that aluminium brass is susceptible to intergranular SCC under the mutual effect of tensile stress and intergranular corrosion.

Cupronickel was most widely used for the high pressure feed water heater tubes of thermal power plants with the capacity of less than $100 \mathrm{MW}$, constructed before 1960 in Japan, as shown in Table 1. We have experienced a few number of failures of $90 / 10$ and 70/30 cupronickel by SCC. ${ }^{6)}$ The 70/30 cupronickel failed longitudinally at the portion of $U$ bend from the steam side after service time of about 5 years. The cracks penetrated through the tube wall intergranularly accompanied by intergranular corrosion of 5 to 10 grains. The tubes were covered with the thick dark brown scale which consisted of the oxides of alloying elements $\left(\mathrm{Cu}_{2} \mathrm{O}, \mathrm{NiO}\right.$ and $\left.\mathrm{Fc}_{3} \mathrm{O}_{4}\right)$, as the same ratio as the material composition. The $90 / 10$ cupronickel also suffered the circumferential cracks at the end of roller expansion from the high pressurized water side and the longitudinal cracks at the straight portion from the steam side, after the service time of 2 to 4 years. Both of them were observed along the grain boundary. The inspection of mechanical properties of the failed and sound tubes revealed that the relief of residual stresses during manufacturing was not enough in the failed tubes.

Stress relieved Monel metal has been used for the high pressure feed water heater tubes of modern thermal power plants with the capacity of 100 to 350 MW since 1960 in Japan, as shown in Table 1.

Table 1. The historical change of tube materials used for high pressure feed water heaters at thermal power plants in Japan.

\begin{tabular}{ccccr}
\hline Generating & Date of & \multicolumn{3}{c}{ Number of turbin plants } \\
\cline { 3 - 5 } power (MW) & construction & $70 / 30$ cupronickel & Monel metal & Carbon steel \\
\hline 100 & -1960 & 45 & 1 & 3 \\
$100-200$ & $1960-1965$ & 6 & 50 & 5 \\
$200-400$ & $1962-1970$ & 0 & 31 & 23 \\
400 & $1970-$ & 0 & 0 & 6 \\
\hline
\end{tabular}


We have investigated several examples of the trouble due to SCC in Monel metals. In this paper we describe the case of a certain power plant. This power plant has three turbins, unit 1,2 and 3, of which the Monel tubes for high pressure feed water heaters were supplied by different tube makers, A, B and C, respectively. The cracks of tubes occurred at each turbin, as summarized in Table 2. The cracks of $\mathrm{A}$ and $\mathrm{B}$ tubes occurred from the water side at the portions of $U$ bend in the minimum radius of $35 \mathrm{~mm}$ and at the end of roller expansion. On the other hand, the cracks of $\mathrm{C}$ tubes occurred longitudinally from the steam side at the straight portion near the entrance of steam. The inner surfaces of A and B tubes were covered with the thin reddish brown scale at upper layer and with the tenacious dark brown scale at lower layer. However, the outer surfaces of $\mathrm{C}$ tubes remained nearly bright. By the analysis of surface scales on $\mathrm{B}$ and $\mathrm{C}$ tubes, it became clear that the surface scales consisted of the metallic copper and the oxides of alloy elements as shown in Table 3. The typical appearance and the microstructure of a failed $\mathbf{t}$ ube are shown in Fig. 2. It shows intergranular penetration accompanied by slight intergranular corrosion of 1 to 2 grains. The other cracked tubes showed the similar morphology except the failure of six tubes belonging to $\mathrm{B}$, which penetrated the tube wall transgranularly due to corrosion fatigue. Table 4 shows the mechanical properties of failed tubes. All tubes are out of the standards of the stress relieved

Table 2. Details of cracking of Monel metal tubes served for high pressure feed water heaters at the A power plant.

\begin{tabular}{cccccccc}
\hline \hline $\begin{array}{c}\text { Turbin } \\
\text { number }\end{array}$ & $\begin{array}{c}\text { Supplier } \\
\text { of tube }\end{array}$ & $\begin{array}{c}\text { Duration } \\
\text { of } \\
\text { operation }\end{array}$ & $\begin{array}{c}\text { Heater } \\
\text { number of } \\
\text { trouble }\end{array}$ & $\begin{array}{c}\text { Portion } \\
\text { of cracks }\end{array}$ & $\begin{array}{c}\text { Number of } \\
\text { cracked } \\
\text { tubes }\end{array}$ & $\begin{array}{c}\text { Initiation } \\
\text { of cracks }\end{array}$ & $\begin{array}{c}\text { Morphology } \\
\text { of cracks }\end{array}$ \\
\hline 1 & A & $\begin{array}{c}\text { Jan. '63- } \\
\text { Dec. '67 }\end{array}$ & $\begin{array}{l}\text { No. } 5 \\
\text { No. } 5\end{array}$ & $\begin{array}{l}\text { U bend } \\
\text { expansion }\end{array}$ & 7 & water side & intergranular \\
\hline 2 & B & $\begin{array}{c}\text { May '63- } \\
\text { Dec. '71 }\end{array}$ & $\begin{array}{l}\text { No. } 5 \\
\text { No. 5; } 6\end{array}$ & $\begin{array}{l}\text { U bend } \\
\text { expansion }\end{array}$ & 7 & water side & intergranular \\
\hline 3 & C & $\begin{array}{c}\text { Aug. '69- } \\
\text { Dec. '71 }\end{array}$ & No. 6 & straight & 9 & steam side & intergranular \\
\hline
\end{tabular}

Table 3. Results of analysis of the surface scale on Monel metal tubes.

\begin{tabular}{|c|c|c|c|c|c|}
\hline Tube & Portion & & Method & Results & \\
\hline \multirow[b]{3}{*}{ B } & \multirow[b]{3}{*}{$\begin{array}{l}\text { Inner surface } \\
\text { of tube }\end{array}$} & Upper layer & $\mathrm{X}$ ray diffraction & $\mathrm{Cu} \quad \mathrm{Cu}_{2} \mathrm{O}$ & \\
\hline & & \multirow[b]{2}{*}{ Lower layer } & $\mathrm{X}$ ray diffraction & $\mathrm{NiO}$ & \\
\hline & & & $\begin{array}{l}\text { Electron microprobe } \\
\text { analyser }\end{array}$ & $\begin{array}{l}\mathrm{Cu}: 5.8-6.8 \% \\
\mathrm{Ni}: 39.0-57.8 \% \\
\mathrm{Fe}: 5.8-10.1 \% \\
\mathrm{O}: 31.0-32.2 \%\end{array}$ & \\
\hline \multirow[b]{2}{*}{$\mathrm{C}$} & \multirow[b]{2}{*}{$\begin{array}{l}\text { Outer surface } \\
\text { of tube }\end{array}$} & & $\mathrm{X}$ ray diffraction & $\mathrm{Cu} \quad \mathrm{Cu}_{2} \mathrm{O}$ & $\mathrm{NiO}$ \\
\hline & & & $\begin{array}{l}\text { Electron microprobe } \\
\text { analyser }\end{array}$ & $\begin{array}{l}\mathrm{Cu}: 48.6-54.6 \% \\
\mathrm{Ni}: 6.5-9.8 \% \\
\mathrm{Fe}: 13.7-19.5 \% \\
\mathrm{O}: 17.7-19.8 \%\end{array}$ & \\
\hline
\end{tabular}

Table 4. Mechanical properties of Monel metal tubes failed in high pressure feed water heater.

\begin{tabular}{|c|c|c|c|c|c|c|c|c|}
\hline & \multirow{3}{*}{$\begin{array}{c}\begin{array}{c}\text { Supplier of } \\
\text { Monel metal tubes }\end{array} \\
\text { A }\end{array}$} & \multirow{2}{*}{\multicolumn{2}{|c|}{\begin{tabular}{cc}
\multicolumn{3}{r}{ Tensile properties } \\
$\sigma_{0.2}$ & $\sigma_{\mathrm{B}}$ \\
$\left(\mathrm{kg} / \mathrm{mm}^{2}\right)$ & $\left(\mathrm{kg} / \mathrm{mm}^{2}\right)$
\end{tabular}}} & \multirow{3}{*}{$\begin{array}{l}\begin{array}{l}\delta \\
(\%)\end{array} \\
19.5\end{array}$} & \multicolumn{2}{|c|}{ Hardness } & \multicolumn{2}{|c|}{ Residual stress } \\
\hline & & & & & $\mathrm{H}_{\mathrm{R}} \mathrm{B}$ & $\mathrm{H}_{\mathrm{V}}$ & $\begin{array}{c}\sigma \theta \\
\left(\mathrm{kg} / \mathrm{mm}^{2}\right)\end{array}$ & $\begin{array}{c}\sigma_{i} \\
\left(\mathrm{~kg} / \mathrm{mm}^{2}\right)\end{array}$ \\
\hline \multirow{3}{*}{$\begin{array}{l}\text { Failed } \\
\text { tubes }\end{array}$} & & 59.8 & 72.4 & & (97.5) & 229 & 23.2 & 7.6 \\
\hline & B & 55.6 & 74.2 & 21.9 & (95) & 217 & 8.9 & 2.9 \\
\hline & $\mathrm{C}$ & 61.8 & 75.6 & 20.6 & 100 & (249) & N.D. & N.D. \\
\hline $\begin{array}{c}\text { Standards } \\
\text { or SRT }\end{array}$ & - & $>38.5$ & $>60$ & $>20$ & $85-97$ & $(167-227)$ & - & - \\
\hline
\end{tabular}

( ): Value of conversion number for nickel and high nickel alloys described in ASTM. 

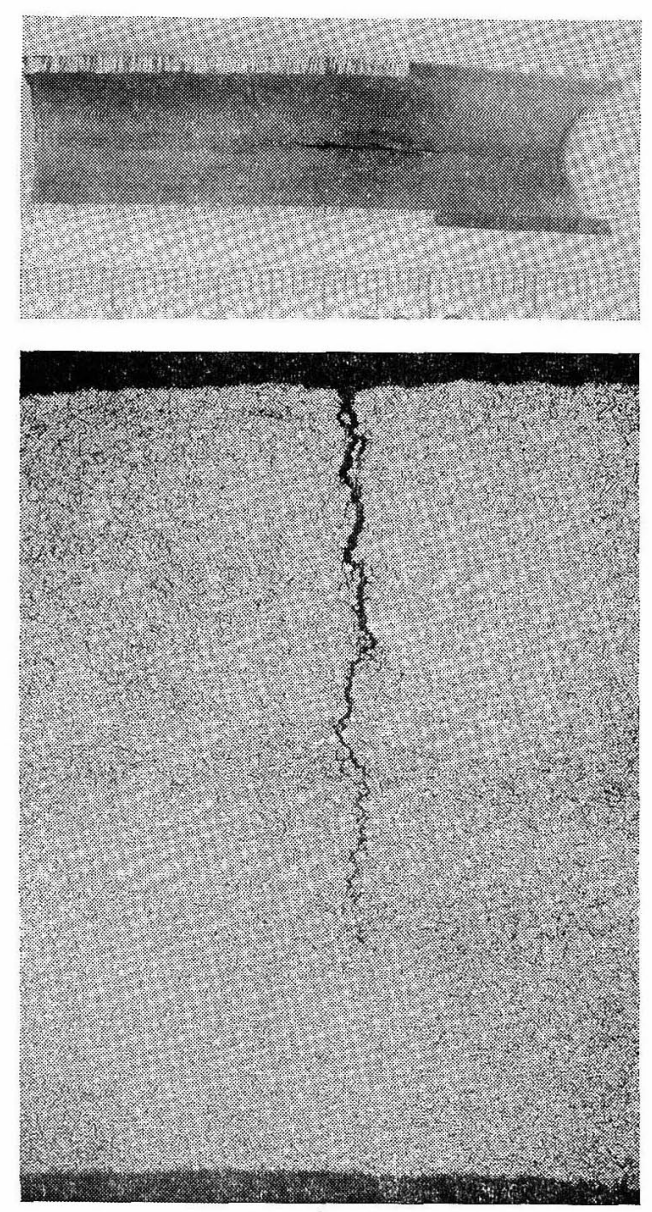

$300 \pi$

Fig. 2. Typical stress corrosion cracking of Monel metal served for high pressure feed water heater. tubes in any points, that is, residual stress, elongation, and hardness. Especially the tube $\mathrm{C}$ shows very high hardness of $\mathrm{H}_{\mathrm{R}} \mathrm{B} 100$ and may be considered to leave high internal stresses. The stressed condition to cause SCC of the tube C may be due to the internal residual stress during manufacturing. On the other hand, in the cases of A and $B$ tubes, internal stress may arise by the subsequent deformation, such as $U$ bend and roller expansion, in addition to be residual stress in manufacturing.

\section{Laboratory Research}

\subsection{Experimental}

The materials used in this study are shown in Table 5, with their chemical composition and mechanical properties. Each alloy was melted, casted and rolled to $0.50 \mathrm{~mm}$ sheet and finished in condition of full annealing or $10 \%$ cold rolling. Tensile specimens having gage dimensions of $20 \mathrm{~mm}$ $\times 3 \mathrm{~mm}$ were stamped. They were fixed to the specially devised holder and loaded uniaxially by mcans of a 18-8 stainless steel spring and then tested in 5 liter autoclaves made of 18-8 stainless steel as shown in Fig. 3. Two liters of distilled water as test solution was introduced into the autoclave. After being degassed at $110^{\circ} \mathrm{C}$ or introduced oxygen of 3 to $10 \mathrm{~kg} / \mathrm{cm}^{2}$ at ambient temperature, the autoclave was heated to test temperatures of 150 to $350^{\circ} \mathrm{C}$. Measured oxygen content was $0.1-0.3 \mathrm{ppm}$ and $40-70 \mathrm{ppm}$ under degassed and oxygen bearing conditions, respectively. After a certain period, the frames containing the tensile specimens were taken out of the autoclave and the weight change, the degree of loss

Table 5. Chemical composition and mechanical properties of the spccimens prepared to autoclave tests.

\begin{tabular}{|c|c|c|c|c|c|c|c|c|c|c|}
\hline \multicolumn{7}{|c|}{ Chemical composition (wt \%) } & \multicolumn{4}{|c|}{ Mechanical properties } \\
\hline $\mathrm{Cu}$ & $\mathrm{Zn}$ & Al & $\mathrm{Ni}$ & $\mathrm{Fe}$ & Mn & As & $\begin{array}{c}\text { Condition } \\
\text { of } \\
\text { specimen }\end{array}$ & $\left(\mathrm{kg} / \mathrm{mm}^{2}\right)$ & $\begin{array}{c}\sigma \mathrm{B} \\
\left(\mathrm{kg} / \mathrm{mm}^{2}\right)\end{array}$ & $\begin{array}{c}\delta \\
(\%)\end{array}$ \\
\hline $\mathrm{R}$ & 5.0 & 0.90 & - & - & - & - & $10 \%$ C.R. & 24.9 & 29.8 & 30 \\
\hline $\mathrm{R}$ & 10.5 & 0.95 & - & - & - & - & $10 \%$ C.R. & 32.3 & 34.6 & 34 \\
\hline $\mathrm{R}$ & 20.5 & 0.94 & - & - & - & 一 & $10 \%$ C.R. & 26.8 & 38.2 & 48 \\
\hline $\mathrm{R}$ & 30.2 & 0.94 & - & - & - & - & $10 \%$ C.R. & 25.4 & 36.9 & 45 \\
\hline 77.9 & $\mathrm{R}$ & 2.0 & - & - & - & 0.05 & $10 \%$ C.R. & 31.0 & 44.4 & 47 \\
\hline \multirow[t]{2}{*}{$\mathrm{R}$} & - & - & 10.14 & 1.18 & 0.45 & - & annealed & 9.0 & 32.8 & 35 \\
\hline & & & & & & & $10 \%$ C.R. & 27.0 & 33.5 & 16 \\
\hline \multirow[t]{2}{*}{$\mathrm{R}$} & - & - & 30.53 & 0.60 & 0.66 & - & annealed & 13.1 & 41.5 & 40 \\
\hline & & & & & & & $10 \%$ C.R. & 36.9 & 43.6 & 22 \\
\hline \multirow[t]{2}{*}{30.5} & - & - & $\mathrm{R}$ & 1.28 & 0.96 & - & annealed & 21.8 & 58.4 & 40 \\
\hline & & & & & & & $10 \%$ C.R. & 44.9 & 55.4 & 24 \\
\hline
\end{tabular}




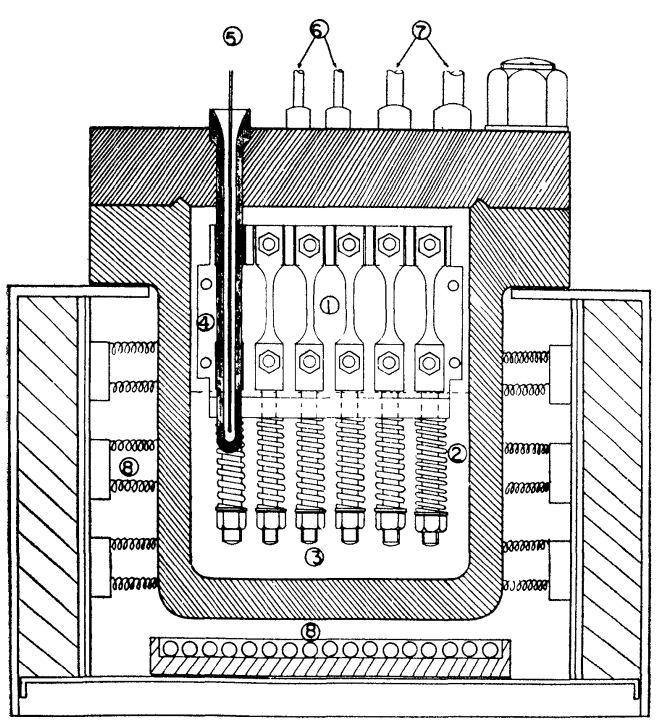

Fig. 3. Section of autoclave. (1) Specimen, (2) Spring, (3) Water, (4) Frame for specimen holder, (5) Thermocouple, (6) Valve,

(7) Pressure gauge, (8) Heating coil.

in tensile properties and the corrosion morphology were inspected.

\subsection{Results of the Autoclave Tests}

\subsection{1 $\mathrm{Cu}-\mathrm{Zn}-\mathrm{Al}$ alloys}

Preliminary corrosion tests without applied tensile stress have been made on $\mathrm{Cu}-0$ to $30 \% \mathrm{Zn}-0$ o $3 \% \mathrm{Al}$ alloys of $\alpha$ single phase in the degassed steam under saturated pressure at 200 to $350^{\circ} \mathrm{C}$

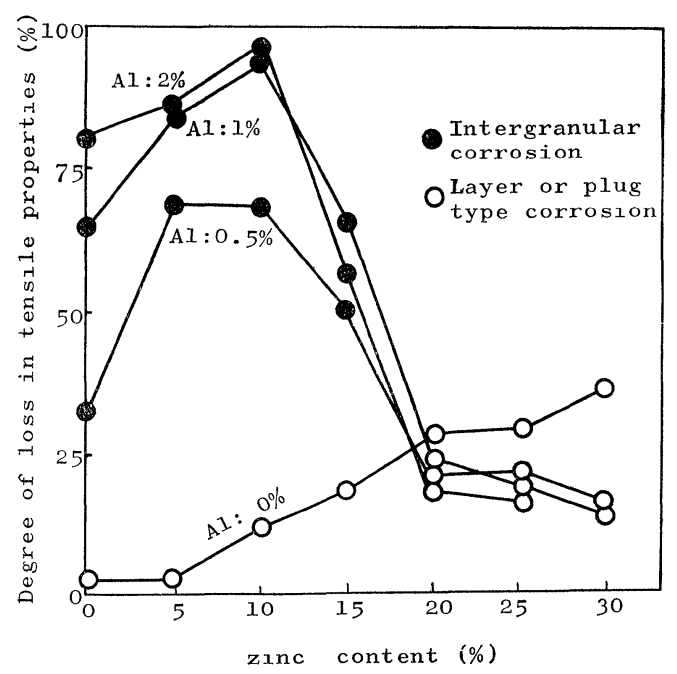

Fig. 4. The effect of alloy composition on the corrosion morphology and degree of loss in tensile properties for $\mathrm{Cu}-\mathrm{Zn}-\mathrm{Al}$ alloys exposed to degassed steam at $250^{\circ} \mathrm{C}$ for $3,000 \mathrm{hrs}$. for $3,000 \mathrm{hrs}$. The results of tests at $250^{\circ} \mathrm{C}$ are shown in Fig. 4. The $\mathrm{Cu}-\mathrm{Zn}-\mathrm{Al}$ ternary alloys showed two types of corrosion morphology according to zinc content. Namely, the alloys of less than $15 \% \mathrm{Zn}$ suffered intergranular type corrosion, while the alloys of more than $20 \% \mathrm{Zn}$ suffered layer type corrosion. Moreover, as steam temperature becomes lower, the alloys are apt to suffer intergranular corrosion. Aluminium content in the range of 0.5 to $3 \%$ had little influence on the corrosion morphology. The depth of corrosion decreased with zinc content contrary to that of $\mathrm{Cu}-\mathrm{Zn}$ binary alloys. The degree of loss in tensile properties increased remarkably with the depth of intergranular corrosion, but it did not increase with the depth of layer corrosion. The results of this test indicate that $\mathrm{Cu}-30 \% \mathrm{Zn}-0.5$ to $1.5 \% \mathrm{Al}$ alloys have the most excellent resistance to corrosion.

The effects of applied tensile stress on the corrosion behavior were investigated. The cold rolled specimens of $\mathrm{Cu}-\mathrm{Zn}-\mathrm{Al}$ alloys shown in Table 5 were exposed to degassed steam at $250^{\circ} \mathrm{C}$ for $500 \mathrm{hrs}$ under applied tensile stresses corresponding to 20 to $50 \%$ of the proof stresses. All specimens slightly increased by weight of about $0.1 \mathrm{mg} / \mathrm{cm}^{2}$, forming the tenacious dark red corrosion products. The experimental results are shown in Fig. 5. The intergranular corrosion of low zinc alloys was accelerated under applied stress corresponding to $20 \%$ of proof stress (about $5 \mathrm{~kg} / \mathrm{mm}^{2}$ ). The tensile test reveals that the degree of loss in tensile properties is in agreement with the degree of corrosion attack. On the other hand, the layer type corrosion of high zinc alloys was not influenced by applied tensile stress up to $50 \%$ of proof stress. However, the alloys stressed 50\% of proof stress showed the appreciable amount of loss in tensile properties, which was regarded as the damage by intergranular cavitation mechanism. Further detailed tests were made on $\mathrm{Cu}-$ $30 \% \mathrm{Zn}-1 \% \mathrm{Al}$ alloy, which had the most excellent resistance in preliminary non-stressed corrosion tests. It was observed that this alloy was deteriorated not by SCC but by intergranular cavitation fracture at relatively low level of applied stress, $3 \mathrm{~kg} / \mathrm{mm}^{2}, \quad 5 \mathrm{~kg} / \mathrm{mm}^{2}$ and $10 \mathrm{~kg} / \mathrm{mm}^{2}$ at $300^{\circ} \mathrm{C}, 250^{\circ} \mathrm{C}$ and $200^{\circ} \mathrm{C}$, respectively.

A commercial aluminium brass was tested in the degassed steam at 200 to $300^{\circ} \mathrm{C}$ for $1,000 \mathrm{hrs}$ under applied tensile stress. The experimental results are shown in Fig. 6. This alloy suffered intergranular corrosion at 200 to $250^{\circ} \mathrm{C}$, which 


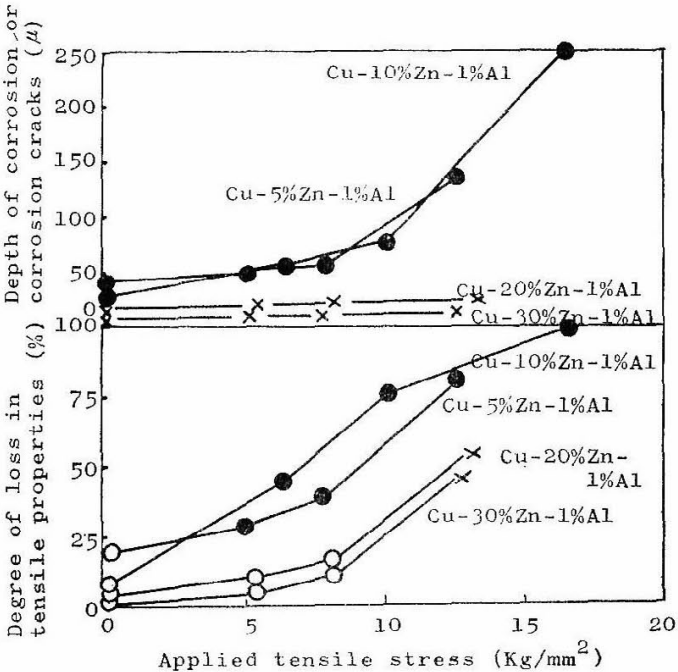

Fig. 5. The effect of applied tensile stress on the corrosion behaviour of $\mathrm{Cu}-\mathrm{Zn}-\mathrm{Al}$ alloys exposed to degassed steam at $250^{\circ} \mathrm{C}$ for 500 hrs.

upper figure: $\left\{\begin{array}{l}\text { Intergranular corrosion } \\ \times \text { Layer type corrosion }\end{array}\right.$

- Intergranular stress corrosion cracking

lower figure: $\left\{\begin{array}{l}\text { (I. S. C. C.) } \\ \text { (nterganget }\end{array}\right.$

$\times$ Intergranular cavitation fracture

O None cracks
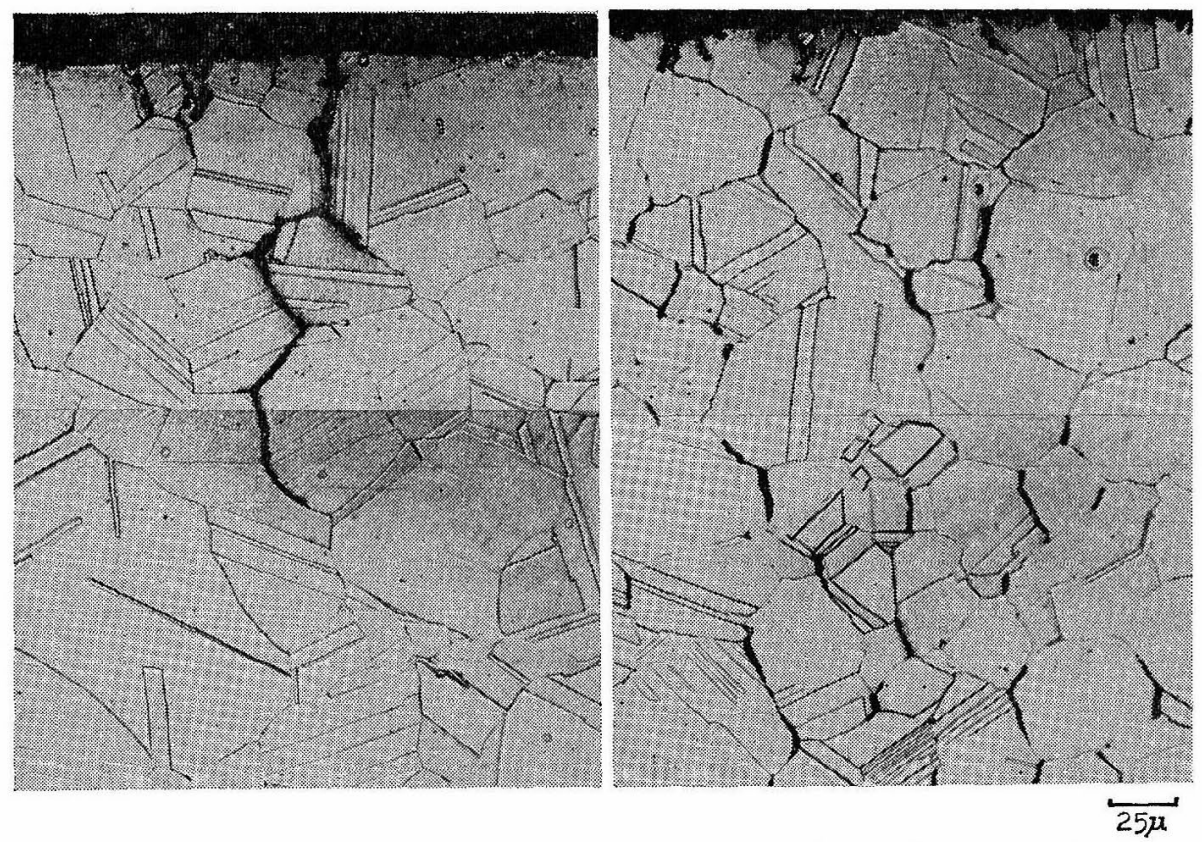

Fig. 7. Stress corrosion cracking and typical intergranular cavitation fracture of aluminium brass exposed to $250^{\circ}$ steam under applied tensile stresses. developed to the intergranular SCC under applied tensile stress. However, it suffered plug or layer type corrosion at $300^{\circ} \mathrm{C}$ and the alloy was deteriorated by intergranular cavitation under applied tensile stress. Typical SCC and intergranular cavitation are shown in Fig. 7. The level of tensile stress capable of cracking in this alloy is $5 \mathrm{~kg} / \mathrm{mm}^{2}$, $10 \mathrm{~kg} / \mathrm{mm}^{2}$ and $15 \mathrm{~kg} / \mathrm{mm}^{2}$ at $300^{\circ} \mathrm{C}, 250^{\circ} \mathrm{C}$ and

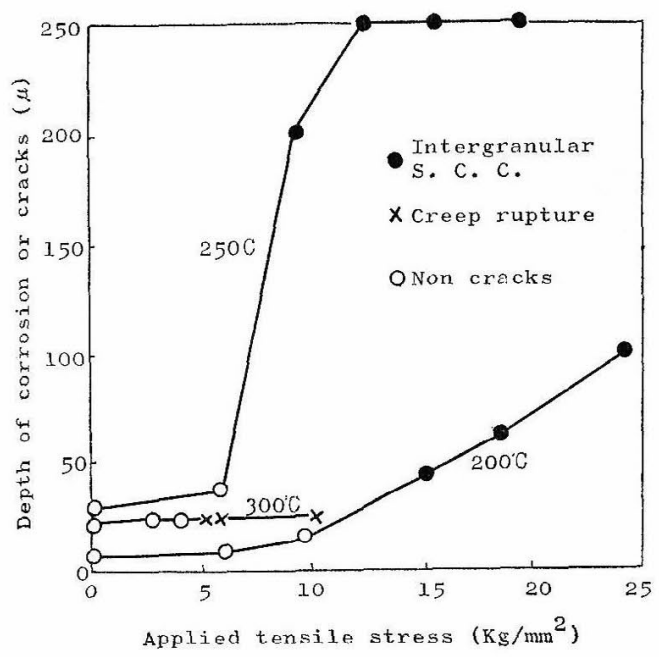

Fig. 6. The effect of applied tensile stress on the depth of corrosion or cracks for commercial aluminium brass exposed to degassed steam at $200^{\circ} \mathrm{C}$ to $300^{\circ} \mathrm{C}$ for 1,000 hrs. 
$200^{\circ} \mathrm{C}$, respectively. The effects of grain size were examined under the condition of tensile stress of $10 \mathrm{~kg} / \mathrm{mm}^{2}$ and test temperature of $180^{\circ} \mathrm{C}$. The alloy of large grain size of $0.1 \mathrm{~mm}$ failed by intergranular corrosion within $750 \mathrm{hrs}$. On the other hand, the alloy of small grain size of 0.01 to $0.02 \mathrm{~mm}$ suffered from neither intergranular corrosion nor cracks up to $2,500 \mathrm{hrs}$. It is considered that the resistance of commercial aluminium brass to $\mathrm{SCC}$ is remarkably dependent upon grain size.

\subsubsection{Cupro-nickel}

The accelerated tests of $90 / 10$ and 70/30 cupronickel alloys were made repeatedly in the autoclaves for $500 \mathrm{hrs}$ under the various conditions including the parameters such as test temperature, oxygen content, applied tensile stress and temper of specimen. The experimental results are summarized in Table 6. The alloys exposed to degassed steam remained bright surface and showed slight weight gain. They suffered intergranular corrosion of which depth was 30 to $50 \mu$. On the other hand, the alloys exposed to oxygen bearing steam suffered severe corrosion of exfoliating and subsequent intergranular corrosion of which depth was 50 to $100 \mu$. It was found in several runs of the tests that the rate of intergranular corrosion was accelerated by the applied stress. These data indicate that SCC might occur regardless of alloy composition, temper of specimen, steam temperature and oxygen content. The level of tensile stress capable of accelerating intergranular corrosion is estimated to be 15 to $20 \mathrm{~kg} / \mathrm{mm}^{2}$ which is approximately corresponding to $50 \%$ of proof stress of cold rolled specimens. Typical examples of SCC are shown in Fig. 8.

\subsubsection{Monel metal}

Monel metal was tested repeatedly six times at $350^{\circ} \mathrm{C}$ in the steam and water of various oxygen

Table 6. Results of autoclave SCC tests under various conditions with specimens of $90 / 10$ and $70 / 30$ cupronickel alloys.

\begin{tabular}{|c|c|c|c|c|c|c|c|}
\hline \multirow[b]{2}{*}{ Alloy } & \multicolumn{4}{|c|}{ Condition of tests } & \multicolumn{3}{|c|}{ Results of tests } \\
\hline & $\underset{\left({ }^{\circ} \mathrm{C}\right)}{\text { Temp. }}$ & Medium & $\begin{array}{c}\text { Stress } \\
\text { level } \\
\left(\mathrm{kg} / \mathrm{mm}^{2}\right)\end{array}$ & $\begin{array}{c}\text { Condition } \\
\text { of } \\
\text { specimen }\end{array}$ & $\begin{array}{l}\text { Depth of } \\
\text { intergranular } \\
\text { corrosion }(\mu)\end{array}$ & SCC & $\begin{array}{l}\text { Threshold } \\
\text { stress } \\
\left(\mathrm{kg} / \mathrm{mm}^{2}\right)\end{array}$ \\
\hline \multirow{16}{*}{ 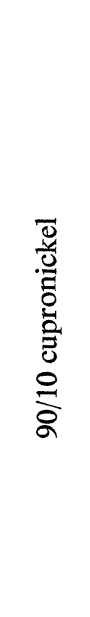 } & \multirow[t]{3}{*}{300} & degassed & $8.1-27.0$ & $10 \%$ C.R. & $16-20$ & Yes & $(16.2)$ \\
\hline & & oxygen bearing & $9.8-22.8$ & annealed & $28-40$ & None & $(-)$ \\
\hline & & oxygen bearing & $5.4-21.6$ & $10 \%$ C.R. & $45-50$ & Yes & (13.5) \\
\hline & \multirow[t]{11}{*}{350} & degassed & $2.7-15.3$ & annealed & 40 & Yes & $(15.3)$ \\
\hline & & degassed & $9.8-22.8$ & annealed & 20 & Yes & (13.5) \\
\hline & & degassed & $5.4-27.0$ & $10 \%$ C.R. & 35 & Yes & $(13.5)$ \\
\hline & & degassed & $2.7-16.2$ & $10 \%$ C.R. & 30 & None & $(-)$ \\
\hline & & degassed & $8.1-27.0$ & $10 \%$ C.R. & 55 & Yes & $(13.5)$ \\
\hline & & oxygen bearing & $2.7-15.3$ & annealed & 90 & Yes & $(13.5)$ \\
\hline & & oxygen bearing & $9.8-22.8$ & annealed & 50 & Yes & $(22.8)$ \\
\hline & & oxygen bearing & $12.3-22.8$ & annealed & 70 & Yes & (12.3) \\
\hline & & oxygen bearing & $13.5-27.0$ & $10 \%$ C.R. & 125 & Yes & (13.5) \\
\hline & & oxygen bearing & $5.4-27.0$ & $10 \%$ C.R. & 140 & Yes & $(13.5)$ \\
\hline & & oxygen bearing & $2.7-16.2$ & $10 \%$ C.R. & 40 & None & $(-)$ \\
\hline & \multirow[t]{2}{*}{300} & degassed & $11.0-33.2$ & $10 \%$ C.R. & 50 & Yes & $(11.0)$ \\
\hline & & oxygen bearing & $7.4-32.0$ & $10 \%$ C.R. & 59 & Yes & (11.1) \\
\hline \multirow{12}{*}{ 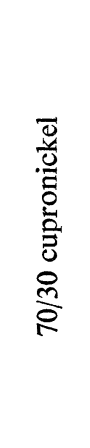 } & \multirow[t]{12}{*}{350} & degassed & $3.9-17.0$ & annealed & 43 & None & $(-)$ \\
\hline & & degassed & $15.8-28.7$ & annealed & 55 & Yes & $(15.8)$ \\
\hline & & degassed & $12.6-28.7$ & annealed & 18 & None & $(-)$ \\
\hline & & degassed & $18.5-32.1$ & $10 \%$ C.R. & 49 & Yes & (18.5) \\
\hline & & degassed & $7.4-32.1$ & $10 \%$ C.R. & 30 & None & $(-)$ \\
\hline & & degassed & $3.9-22.1$ & $10 \%$ C.R. & 40 & None & $(-)$ \\
\hline & & oxygen bearing & $10.5-17.0$ & annealed & 98 & None & $(-)$ \\
\hline & & oxygen bearing & $15.8-28.7$ & annealed & 92 & Yes & $(20.5)$ \\
\hline & & oxygen bearing & $12.6-28.7$ & annealed & 84 & None & \\
\hline & & oxygen bearing & $15.5-32.1$ & $10 \%$ C.R. & 66 & Yes & $(18.5)$ \\
\hline & & oxygen bearing & $7.4-29.6$ & $10 \%$ C.R. & 90 & Yes & $(18.5)$ \\
\hline & & oxygen bearing & $3.7-22.1$ & $10 \%$ C.R. & 65 & Yes & $(18.5)$ \\
\hline
\end{tabular}




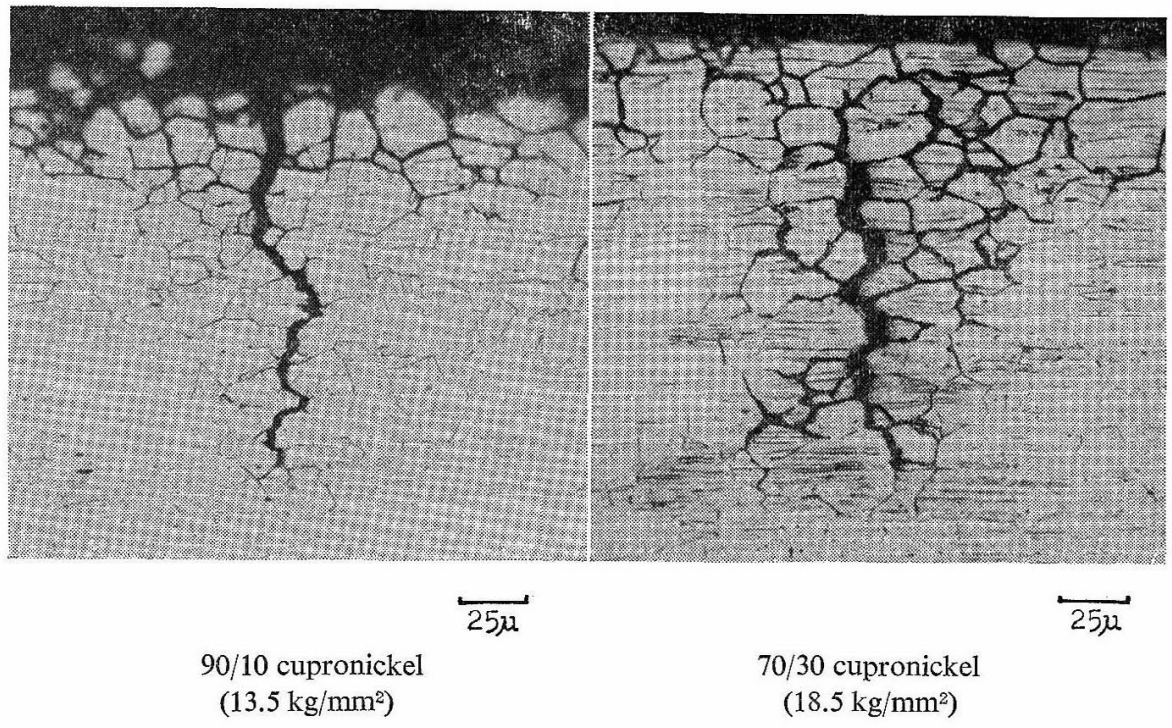

Fig. 8. Stress corrosion cracking of $90 / 10$ and $70 / 30$ cupronickel alloys exposed to degassed steam at $350^{\circ} \mathrm{C}$ for $500 \mathrm{hrs}$ under applied stresses.

content for $500 \mathrm{hrs}$ under applied tensile stress up to $38 \mathrm{~kg} / \mathrm{mm}^{2}$. They suffered the layer type corrosion and subsequently the intergranular type corrosion. The depth of layer type corrosion became deep with the increase in oxygen content but the depth of intergranular corrosion was observed to be only 5 to $10 \mu$ regardless of the oxygen content. In all tests repeated six times, the corrosion rate was not accelerated by applied tensile stress. The tests in aerated steam and water $\left(\mathrm{O}_{2}=4-7 \mathrm{ppm}\right)$ were carried out until 3,000 hrs. The depth of layer type corrosion increased with the test duration, but the depth of intergranular corrosion remained about $10 \mu$. As far as these experiments are concerned, Monel metal is recognized to be immune to SCC in high temperature water and steam.

\section{Discussion}

(1) The $\mathrm{Cu}-\mathrm{Zn}-\mathrm{Al}$ alloys showed two types of corrosion morphology in high temperature steam according to their alloy composition. Namely, the low zinc alloys were apt to suffer the intergranular corrosion, which developed to the cracks under applied tensile stress. This phenomenon is considered to be SCC in a broad sense. While the alloys of high zinc had a tendency to suffer the layer type corrosion. Therefore, the high zinc alloys were concluded to be immune to SCC inevitably, as confirmed by the autoclave tests. From a practical point of view, the high zinc alloys, for example $\mathrm{Cl}-30 \% \mathrm{Zn}-1 \% \mathrm{Al}$, were considered to be the most excellent alloys in $\mathrm{Cu}-\mathrm{Zn}-\mathrm{Al}$ system. It was observed, however, that these alloys were tended much to be deteriorated by intergranular cavitation fracture. This phenomenon has been investigated from the point of view of physical metallurgy. The intergranular corrosion which is characteristic of low zinc alloys may be associated with equilibrium grain boundary segregation of active metals, as Klement et al. described in $\mathrm{Cu}-\mathrm{Al}$ alloys. ${ }^{11}$

(2) Commercial aluminium brass was apt to suffer the intergranular corrosion and the intergranular SCC when compared with $\mathrm{Cu}-20 \% \mathrm{Zn}-$ $1 \% \mathrm{Al}$ alloy, in spite of nearly the same content of zinc and aluminium. One of the authors has reported the effect of additive elements on the corrosion of $\mathrm{Cu}-\mathrm{Zn}$ and $\mathrm{Cu}-\mathrm{Al}$ alloys in high temperature steam and water." In those papers, he clarified that the addition of small amount of arsenic or antimony promoted remarkably the corrosion of those alloys. Therefore, it is considered that the arsenic of $0.05 \%$ contained in the commercial aluminium brass may affect significantly the intergranular corrosion of this alloy.

(3) The $90 / 10$ and $70 / 30$ cupronickel alloys suffered the intergranular corrosion in high temperature steam. In the autoclave tests the intergranular SCC could be easily reproduced under applied tensile stress. Therefore, it is suggested that in order to avoid the danger of SCC the relief of residual stress in necessary even for cupronickel tubes served in high temperature pure steam and 
water.

(4) On the other hand, though several examples of troubles on Monel metal due to SCC have been experienced in service, the authors were unsuccessful in reproducing the cracking in the pure steam and water at 300 to $350^{\circ} \mathrm{C}$ under the tensile stresses up to $38 \mathrm{~kg} / \mathrm{mm}^{2}$. It was found that Monel metal is highly resistant to SCC in high temperature steam and water. The investigation on the tubes failed in service revealed that hardness values of all of them were higher than the value specified in the standards. Furthermore, the service life of failed tubes was longer than two years. These experiences suggest that the SCC of Monel metal depends upon the metallurgical factor and also upon the duration in service. Therefore, even if we were unsuccessful in reproducing the SCC on Monel metal under the given conditions of the tensile stress and the pure water and steam, it seems not necessarily to conclude that Monel metal is not susceptible to SCC in the pure water and steam. In order to elucidate the phenomenon of SCC of Monel metal in high temperature steam and water, further experiments should be required.

(5) From the facts described above, we may conclude that the phenomenon of SCC of copper alloys in high temperature steam and water is similar to the stress accelerated intergranular corrosion. From a theoretical and practical point of view, it is desirable to investigate this phenomenon further in details.

\section{Acknowledgement}

The authors would like to thank Sumitomo Light Metal Ind. for permission to publish this paper.

(Received Septembèr 18, 1973)

\section{References}

1) J. F. Klement, R. E. Maersch \& P. A. Tully: Corrosion, 15, 295t (1959); 16, 519t (1960).

2) A. J. Fiocco: O.S.W. Seventh Annual Report (July 1, 1967 to June 30, 1968), p. 241, Denver, Colorado (1969).

3) S. D. Reynolds, Jr. \& F. W. Pement: Power, 115, 83 (April, 1971).

4) T. Otsu \& S. Sato: Transactions of the J.I.M., 2, 153 (1961).

5) T. Otsu \& S. Sato: Sumitomo Light Metal Technical Reports, 1, 22 (1960).

6) S. Sato: Journal of the Japan Institute of Metals, 27, 134 (1963).

7) S. Sato: Journal of the Japan Institute of Metals, 25, 471 (1961); 26, 174 (1962). 